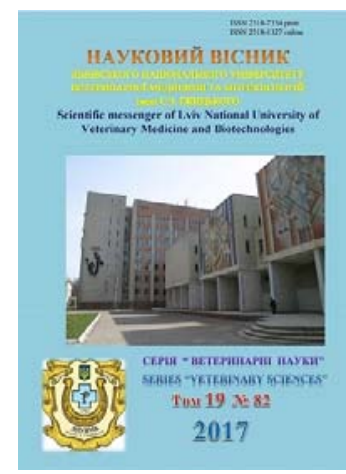

Науковий вісник Львівського національного університету ветеринарної медицини та біотехнологій імені С.З. Гжицького

Scientific Messenger of Lviv National University of Veterinary Medicine and Biotechnologies

doi:10.15421/nvlvet8229

ISSN 2518-7554 print

ISSN 2518-1327 online

http://nvlvet.com.ua/

УДК 578.5/.28:575.856.[543.054:543.635.28]

\title{
Необхідність удосконалення системи моніторингу токсикантів в Україні
}

\author{
Б.I. Назар \\ bobnaz@ukr.net
}

\begin{abstract}
Державний науково-дослідний контрольний інститут ветеринарних препаратів та кормових добавок,
\end{abstract} вул. Донецька, 11, м. Львів, 79019, Україна

У статті наведено основні методичні підходи та критерії щодо необхідності розроблення та впровадження в Україні Державного токсикологічного моніторингу кормів, в тому числі ГМО, враховуючи вимоги до відбору зразків, критерії щодо встановлення його періодичності, аналізу ризиків, вимоги до випробувальних лабораторій.

Наведено основні складові та иілі комплексної системи державного моніторингу ГМО джерел у кормах, кормових добавках, преміксах для сільськогосподарських тварин та птиці. Подано основні методичні підходи та критерії щодо розроблення та впровадження в Украӥні Державного моніторингу кормів за вмістом ГМО, враховуючи вимоги до відбору зразків, встановлення періодичності їх відбору, аналізу ризиків на всіх стадіях ланцюга «виробництво - споживання».

Впровадження токсикологічного моніторингу, в тому числі моніторингу ГМО джерел, у кормах дозволить забезпечити проінформованість, а в подальшому забезпечення охорони здоров'я людини, тварин і навколишнього природного середовища, створить умови для безпечного практичного використання ГМО в господарських иілях, попередить неконтрольоване використання ГМО-джерел кормів.

Ключові слова: моніторинг, корми, кормові добавки, премікси, відбір зразків, генетично модифіковані організми.

\section{Необходимость совершенствования системы мониторинга токсикантов в Украине}

\author{
Б.И. Назар \\ bobnaz@ukr.net
}

Государственный научно-исследовательский контрольный институт ветеринарных препаратов и кормовых добавок, ул. Донеикая, 11, г. Львов, 79019, Украина

В статье приведены основные методические подходы и критерии о необходимости разработки и внедрения в Украине Государственного токсикологического мониторинга кормов, в том числе ГМО, учитывая требования к отбору образцов, критерии для установления его периодичности, анализа рисков, требования к испытательным лабораториям.

Приведены основные составляющие и иели комплексной системы государственного мониторинга ГМО источников в кормах, кормовых добавках, премиксах для сельскохозяйственных животных и птицы. Представлены основные методические подходы и критерии по разработке и внедрению в Украине Государственного мониторинга кормов по содержанию ГМО, учитывая требования к отбору образиов, установления периодичности их отбора, анализа рисков на всех стадиях иепи «производство - потребление».

Внедрение токсикологического мониторинга, в том числе мониторинга ГМО источников, в кормах позволит обеспечить информированность, а в дальнейшем обеспечения охраны здоровья человека, животных и окружающей среды, создаст условия для безопасного практического использования ГМО в хозяйственных иелях, предупредит неконтролируемое использование ГМО-источников кормов.

Ключевые слова: мониторинг, корма, кормовые добавки, премиксы, отбор образцов, генетически модифицированные организмы.

\section{Citation:}

Nazar, B.I. (2017). The need to improve the monitoring system for toxicants in Ukraine. Scientific Messenger LNUVMB, 19(82), 141-144. 


\title{
The need to improve the monitoring system for toxicants in Ukraine
}

\author{
B.I. Nazar \\ bobnaz@ukr.net \\ State Scientific-Research Control Institute of Veterinary Medicinal Products and Feed Additives, \\ Donetska Str., 11, Lviv, 79019, Ukraine
}

The article presents the main methodological approaches and criteria for the necessity of development and introduction of the State Toxicological Monitoring of Forms in Ukraine, including GMOs, taking into account the requirements for sampling, criteria for determining its periodicity, risk analysis, requirements for testing laboratories.

The main components and goals of the complex system of state monitoring of sources of GMOs in feed, feed additives, premixtures for farm animals and poultry are presented. The main methodical approaches and criteria for the development and implementation of the State monitoring of feed in the GMO content in Ukraine are given, taking into account the requirements for the selection of samples, the determination of the frequency of their selection, and the analysis of risks at all stages of the chain "production - consumption».

Implementation of toxicological monitoring, including monitoring of sources of GMOs in feeds, will ensure awareness, and in the future ensure the protection of human, animal and natural environment, will create conditions for the safe practical use of GMOs for economic purposes, prevent uncontrolled use of GMO sources feed.

Key words: monitoring, feeds, feed additives, premixes, sampling, genetically modified objects.

\section{Вступ}

У кожній $з$ країн-членів СОТ, які експортують свою тваринницьку продукцію до інших державчленів організації, здійснення токсикологічного моніторингу є обов'язковою умовою торговельних відносин. Він реалізується згідно із затвердженими планами і є лише частиною загальної системи заходів із контролю за безпекою продуктів харчування. Остання ж базується на наукових даних про фактори небезпеки (збудники зоонозів, промислові та сільськогосподарські токсиканти, залишки ветпрепаратів тощо) та аналізі статистичного матеріалу про частоту й вірогідність їх впливу на споживачів продукції (Syniak, 1999; Sdobodkin, 2008; Hren, 2009).

На основі наукової обробки такої інформації складається щорічний план моніторингу, який має перевірити справедливість теоретичних припущень щодо впливу найбільш небезпечних факторів. Виходячи із результатів реалізації плану державного моніторингу та у випадку виявлення небезпечних факторів у експортній продукції при дослідженні іiі в країніімпортері (повідомлення через систему RASSF), план наступного року повинен коригуватись у бік більш широкого дослідження виявлених факторів ризику. Узагальнення одержаної інформації є основою для подальшого вдосконалення національного законодавства у сфері безпеки продуктів харчування.

Участь України в СОТ вимагає від нас дотримання стандартів у галузі безпеки продуктів харчування на рівні світових вимог.

Основними завданнями науково-методичного забезпечення моніторингу, прогнозування та реагування щодо безпечності продукції тваринного походження в Україні є:

- координація науково-методичних розробок щодо системи токсикологічного моніторингу;

- розроблення концепції забезпечення безпеки i якості продуктів тваринного походження, яка повинна включати принципи контролю критичних точок, про- гнозну мікробіологію і теорію бар'єрів, що дозволить виробляти безпечні продукти;

- розроблення методичних рекомендацій щодо виявлення різноманітних фальсифікацій сировини тваринного походження, включаючи експрес-методи визначення добавок, барвників, підсолоджувачів тощо;

- впровадження нових методів визначення мутагенних і комутагенних властивостей різних харчових інгредієнтів, а також методу обліку ДНК-пошкоджень у різних тканинах і методу ДНК-комет для аналізу ГМО джерел у сировині тваринного походження і м'ясопродуктах;

- створення електронного банку даних щодо забруднювачів кормів та продуктів тваринного походження, їх токсико-гігієнічних характеристик та методів визначення;

- переоснащення наукових та діагностичних лабораторій, підготовка кадрів у сфері аналітичних досліджень методами мас-спектрометричного детектування, газової та високоефективної рідинної хроматографiї, які потрібні для виявлення реальної картини щодо впливу факторів небезпеки;

- необхідність розробки та виробництва в Україні тест-систем для швидкого скринінгу токсикантів у кормах і продуктах харчування;

- розробка узгодженої нормативно-правової бази щодо рівнів МДР окремих токсикантів та залишків ветеринарних препаратів у продукції тваринництва, оскільки чинні нормативи застарілі або ж суперечать один одному;

- застосування сучасних технологій в годівлі тварин, вирощуванні рослин та виробництві продуктів харчування без відповідних регламентів та обмежень призводить до випуску продуктів, передбачити довгостроковий вплив яких на організм споживачів стає неможливим без відповідного науково-методичного обгрунтування;

- інформаційно-аналітичне забезпечення токсикологічного моніторингу, розробка його методології для 
прогнозування появи нових токсикантів та ризиків небезпеки.

Існуюча в Україні система моніторингу токсикантів не охоплює усіх ризиків з боку техногенних факторів щодо безпеки агропродукції. Оскільки організми поглинають і акумулюють токсичні речовини в ланцюгах харчування, то цілком імовірне їх накопичення в біосфері внаслідок відсутності біодеградації (пластмаса, меламін, діоксини тощо).

У програмах моніторингу не передбачено дослідження на попередження забруднення, встановлення критичних точок, розробки системи прогнозування щодо можливого забруднення того чи іншого компонента сировини. Практично відсутні широкомасштабні роботи із гармонізації національних вимог країнвиробників у міжнародному масштабі та наукове обгрунтування впровадження системи НАССР (Hazard Analysis and Critical Control Point), в основі якої $€$ визначення критичних контрольних точок $\mathrm{i}$ аналіз ризиків, пов'язаних із гігієною і безпекою продуктів харчування.

Недостатніми є дослідження у вивченні безпечності продукції тваринництва у зв'язку з екологокліматичними змінами. Відсутні також критерії щодо використання біологічно активних добавок і сировини із вмістом ГМО, а також наночастинок у годівлі тварин та їхній вплив на якість і безпеку продукції тваринного походження, адже для об’єктивної оцінки ефективності трансгенних агробіотехнологій необхідним $€$ вивчення властивостей отримуваних продуктів та їх вплив, як прямий, так і залишковий, на здоров'я тварин і людини.

Дослідження зарубіжних учених із вивчення можливості забруднення продукції тваринництва від тварин та птиці, яким згодовували корми, що містять ГМО джерела, підтвердили відсутність генів чи фрагментів генів генно-модифікованих рослин у м'ясі, молоці, яйцях. Можливість забруднення продуктів тваринного походження ГМО джерелами настає вже на стадії переробки через внесення різноманітних добавок, які можуть містити ГМО. У зв'язку з цим актуальним $\epsilon$ проведення моніторингу поширення ГМО в продукції сільгоспвиробників і розробка вітчизняних ефективних методик оцінки вмісту ГМсировини в зразках агропродукції.

Основними критеріями, які застосовувалися при формуванні плану Державного моніторингу кормів за вмістом ГМО у відповідності до розпорядження СС № 882/2004, були:

- попередження, недопущення або зниження до мінімально можливого рівня ризиків для безпеки людей і тварин пов'язаних 3 кормами безпосередньо або через навколишнє середовище, або підприємствами $з$ переробки, виготовлення кормів, використанням кормів, будь-яким процесом, матеріалом, субстанці$є ю$, діяльністю або операцією, що може впливати на безпеку корму, здоров'я тварини або благополуччя тварин;

- відповідність процедури проведення моніторингу контролю кормів на всіх етапах виробництва, переробки, реалізації, та використання кормів до вимог чинного законодавства;
- наявність відповідних акредитованих випробувальних лабораторій, а також наявність кваліфікованого персоналу для чіткого й ефективного проведення лабораторного контролю;

- наявність у лабораторіях відповідного обладнання та устаткування для проведення лабораторних випробувань кормів;

- наявність системи оповіщення та плану дій у випадку виявлення невідповідних, неякісних та небезпечних кормів;

- зобов'язання суб'єктів господарювання, що виробляють, переробляють, зберігають, реалізують, використовують корми, надавати допомогу співробітникам компетентного органу у виконанні їх задач по контролю безпечності та якості кормів.

Відбір зразків для досліджень є важливим етапом проведення моніторингу, від якого залежить вся подальша ефективність проведеної роботи. Виходячи 3 цього, нами було встановлено загальні принципи та порядок відбору зразків для досліджень. Посадовими особами, які здійснюють відбір зразків для проведення моніторингу в рамках державного ветеринарно-санітарного контролю, є державні інспектори ветеринарної медицини. Відбір зразків проводиться у відповідності до «Порядку відбору зразків продукції тваринного, рослинного i біотехнологічного походження для проведення досліджень» затвердженого постановою Кабінету Міністрів України від 14 червня 2002 р. № 833 та згідно з ДСТУ ISO 6497:2005 Корми для тварин. Методи відбирання проб.

Після кожного відбору зразків оформляється Акт відбору зразків, який дозволяє однозначно ідентифікувати кожну контрольовану партію. Лабораторні зразки, відібрані від кожної партії, потрібно відразу відправити в акредитовану лабораторію, уповноважену Державною та фітосанітарною службою на проведення досліджень iз необхідними супроводжуючими документами. Один лабораторний зразок зберігається в архіві установи, що відібрала зразок для проведення відповідних досліджень.

При встановленні періодичності відбору зразків у виробників кормів для моніторингових досліджень враховували наступні критерії: аналіз ризику; обсяг виробництва; результати офіційного контролю за вмістом ГМО в останні роки; підсумки державного моніторингу кормів за вмістом ГМО за попередні роки; впровадження на підприємстві систем внутрішнього контролю та систем якості; характер використовуваної сировини, кормових добавок, компетентність персоналу, зайнятого у виробництві, кількість скарг та рекламацій, результати їх розслідування, об'єм обігу кормів.

Важливим етапом при проведенні державного моніторингу кормів за вмістом ГМО є аналіз ризику. Він - необхідна умова проведення дій, які гарантують вилучення з обігу кормів, що містять незареєстровані ГМО, які несуть загрозу для здоров'я і життя людей i тварин. Аналіз ризику - процес, що складається 3 трьох взаємозв'язаних елементів: оцінка ризику, керування ним й інформація про нього. Оцінка ризику 
- процес, що складається 3 чотирьох етапів: ідентифікація загроз (наявність незареєстрованих ГМО), характеристика небезпеки (ідентифікація ГМО, його вміст у кормі), оцінка виникнення (встановлення джерел поступленні в корми, ідентифікація сировини, яка містить ГМО, встановлення походження ГМО тощо) i характеристика ризику (встановлення небезпек, які несе незареєстроване ГМО джерело для тварин, людей, навколишнього природнього середовища).

Керування ризиком - процес, що полягає у впровадженні політики та дій для порозуміння із зацікавленими сторонами, вибору способів попередження і контролю ризику, зменшення ризику попадання незареєстрованих ГМО у корми до мінімального можливого рівня. У цьому процесі повинні брати участь всі зацікавлені сторони в залежності від адміністративного рівня, на якому проводиться аналіз ризику: головні державні ветеринарні інспектори районів, областей, Головний держветінспектор України, компетентні органи місцевої влади, зацікавлені суб'єкти господарювання, інші контрольні служби.

Інформація про ризик означає обмін інформацією під час процесу його аналізу і стосуються загроз, чинників, пов'язаних з ним, і попередженням ризику поширення незареєстрованих ГМО джерел кормів.

\section{Висновки}

Впровадження токсикологічного моніторингу, в тому числі моніторингу ГМО джерел, у кормах дозволить забезпечити проінформованість, а в подальшому забезпечення охорони здоров'я людини, тварин i навколишнього природного середовища, створить умови для безпечного практичного використання ГМО в господарських цілях, попередить неконтрольоване використання ГМОджерел кормів.

\section{Бібліографічні посилання}

Rehlament YeS 882/2004 «Pro ofitsiinyi kontrol dlia harantuvannia vidpovidnosti kormiv vymoham zakonodavstva, sanitarii ta blahopoluchchia tvaryn» (in Ukrainian).

Syniak, K. (1999). Shchodo kontseptsii stvorennia merezhi sposterezhennia i laboratornoho kontroliu na terytorii Ukrainy. Nadzvychaini sytuatsii. 8, 13-15 (in Ukrainian).

Hren, H. (2009). Shchodo laboratornoho kontroliu yakosti ta bezpechnosti importovanoi produktsii. Veterynarna medytsyna Ukrainy. 9, 38-40 (in Ukrainian).

Sdobodkin, V.I. (2008). Kontseptualni polozhennia Kodeks Alimentarius ta yikh realizatsiia V natsionalnomu zakonodavstvi Ukrainy. Problemy kharchuvannia. 3/4, 13-22 (in Ukrainian).

Received 2.10.2017

Received in revised form 3.11.2017 Accepted 6.11.2017 